\title{
Particulate Emissions Hazards Associated with Fueling Heat Engines
}

\author{
Robert C. Hendricks ${ }^{1}$ and Dennis Bushnell ${ }^{2}$ \\ ${ }^{1}$ Research and Technology Directorate, NASA Glenn Research Center, 21000 Brookpark Road, Cleveland, OH 44135, USA \\ ${ }^{2}$ NASA Langley Research Center, Hampton, VA 23681, USA
}

Correspondence should be addressed to Robert C. Hendricks, robert.c.hendricks@grc.nasa.gov

Received 24 December 2010; Accepted 18 March 2011

Academic Editor: Zuohua Huang

Copyright (c) 2011 R. C. Hendricks and D. Bushnell. This is an open access article distributed under the Creative Commons Attribution License, which permits unrestricted use, distribution, and reproduction in any medium, provided the original work is properly cited.

\begin{abstract}
All hydrocarbon- (HC-) fueled heat engine exhaust (tailpipe) emissions ( $<10$ to $140 \mathrm{~nm}$ ) contribute as health hazards, including emissions from transportation vehicles (e.g., aircraft) and other $\mathrm{HC}$-fueled power systems. $\mathrm{CO}_{2}$ emissions are tracked and, when mapped, show outlines of major transportation routes and cities. Particulate pollution affects living tissue and is found to be detrimental to cardiovascular and respiratory systems where ultrafine particulates directly translocate to promote vascular system diseases potentially detectable as organic vapors. This paper discusses aviation emissions, fueling, and certification issues, including heat engine emissions hazards, detection at low levels and tracking of emissions, and alternate energy sources for general aviation.
\end{abstract}

\section{Introduction}

Synthetic and biomass fueling of heat engines begins with the generation of feedstocks. For aviation fuels we consider three types: petroleum-based kerosene (JP-8/Jet A-1), synthetic paraffinic kerosene (SPK), and hydro-treated renewable jet (HRJ or bio-SPK or SPK-HEFA (SPK from hydroprocessed esters and fatty acids)). Fueling aircraft with JP-8/Jet A-1 represents legacy and current practice. The SPK process usually begins with coal or natural gas and evolves through a FischerTropsch (FT) process into SPK-fuel and is more common, having a long history within WWII. Biomass fueling (HRJ) is less known, as the process begins with a seed source growing into cellulosic and seed biomass that is converted to biodiesel or seed oil and further processed to jet fuel. In general we consider halophytes, algae, bacteria, weeds-tocrops, and organic waste as fuel feedstocks. Selected plants provide multiple feedstock sources, and we will consider potential fuel feedstock sources such as sustainable palm oil and oil seed plants (e.g., castor) as crops, camelina as a "weed-to-crop," and pennycrest as having "weed-to-seed oil" potential [1-6].

The Makin group sustainable palm-oils are commercially available [1]. Processing castor involves disposing or denaturing highly toxic ricin; camelina is a more conventionally harvested weed-to-crop; and for penneycrest, with weed-tocrop potential, the harvesting and containment of a small weed seed needs consideration. Seed-oil processing to biojet involves crushing, proprietary catalysts and processing, and yields of different hydrocarbon distributions depending on feedstock sources, but all must satisfy the jet fueling standards. Most biomass feedstocks can be handled by the Honeywell-UOP process which converts biomass to biojet by proven processing standards.

Even with SPK or bio-SPK fueling, emissions are still a major problem. Testing of SPK and HRJ provides emissions data including particulate distributions. Similar measurements are made across the transportation industry with heatengine-dependent results. Ground station measurements of $\mathrm{CO}_{2}$ emissions can be used to map out major cities and roadways across the United States. Tailpipe emissions from petroleum-fueled heat engine sources are EPA-designated health hazards. Particulate health hazards are rapidly becoming recognized as a major concern and need resolution. Recent studies show nanometer particulates to engender cardiovascular disease in addition to well-documented respiratory diseases. All hydrocarbon-fueled heat engines produce airborne (exhaust) particulate distributions peaking in the 


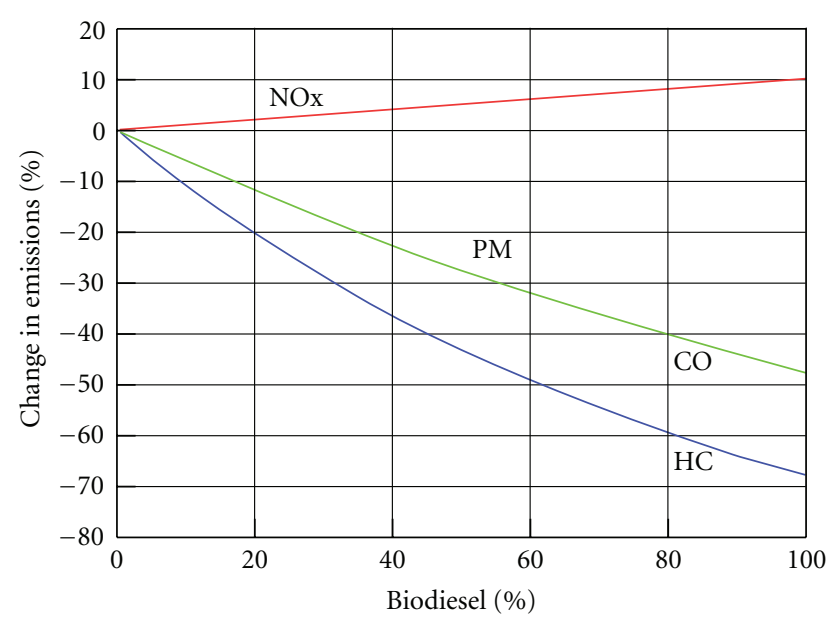

Figure 1: Diesel engine emissions with diesel-biodiesel fueling blends (from [7]).

20 to $40 \mathrm{~nm}$ range, and we can infer that their inhalation is a source of disease. These health concerns are common to all hydrocarbon-fueled heat engines, including aircraft tailpipe emissions, and those flights along the Potomac River are of congressional concern. In this paper we discuss aviation emissions fueling certification, how and why these emissions are hazardous, how they change with additions (SPK or bio-SPK) to JP-8/Jet A-1, and whether we can detect and track them. Hydrocarbon-fueled heat engine emissions are linked to health hazards, implying an emphatic need to curtail hazardous emissions perhaps by transitioning to more electric- or hydrogen-fueled propulsion systems that may offer long-range resolution.

\section{Aviation Emissions, Fueling, and Certification}

In 2006, estimated U.S. national emissions from all sources [12] were $\mathrm{CO}_{2}$ at $1618.5 \mathrm{Mt}$; CO, $100.55 \mathrm{Mt}$; $\mathrm{NOx}, 18.22 \mathrm{Mt}$; volatile organic compounds (VOCs), $17.38 \mathrm{Mt}$; PM10 (coarse particulates), $18.42 \mathrm{Mt}$; PM2.5 (fine particulates), $2.61 \mathrm{Mt} ; \mathrm{SO}_{2}, 13.77 \mathrm{Mt}$; and lead, $4.23 \mathrm{kt}$. Whereas these figures represent all emission sources, we want to focus more on the impact alternate fueling of aviation and heat engines particulates has on human health. Blended fueling with SPK or bio-SPK promotes emissions reductions but does not eliminate them, and without certification standards and rational policy there will not be an alternative fuels market [1]. NASA Glenn Research Center, U.S. Air Force (USAF) and Navy, and commercial aviation are testing alternate aviation fuels and combustor performance as well as metering the emissions from gas turbine engines baselined to conventional petroleum-based fuels (Jet A1) [13-15]. These alternate fuels include those derived from an FT process, resulting in synthetic paraffinic hydrocarbons (SPK) (e.g., coal-to-liquid (CTL) or gas-to-liquid (GTL)) as well as those derived from biomass such as seed oils, pyrolysis oils, and fermentation oils. These oils are further processed to bio-SPK or HRJ.

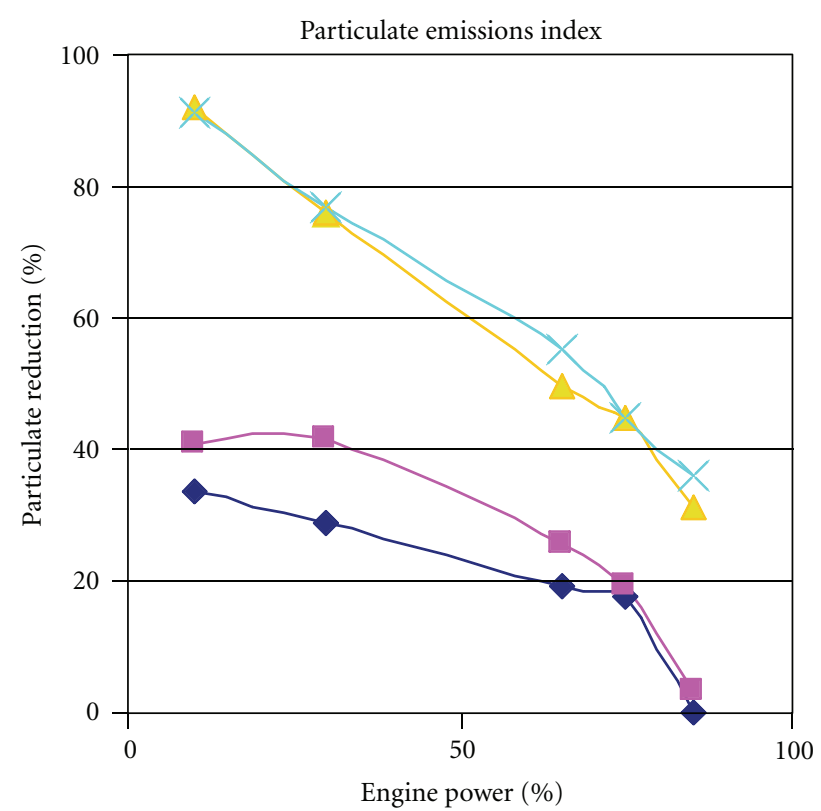

AFRL 50:50 Nasa 50:50

AFRL 100Synl2 Nasa 100Syn

(a)

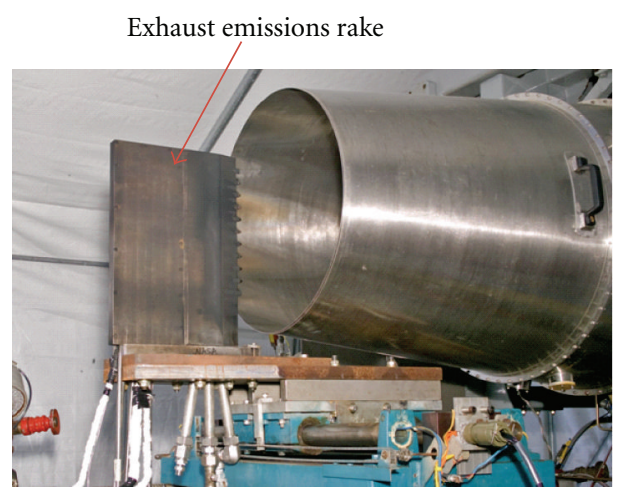

(b)

Figure 2: Civil (NASA) and military (Air Force Research Laboratories, AFRL) engine emissions testing with SPK/Jet A-1 fueling blends.

The biomass feedstocks for fuels we are studying consist of halophytes, algae, bacteria, weeds-to-crops, and wastes.

2.1. Commercial and Military. Flight tests have been carried out with CTL, GTL, and biojet blends up to $50 \%$ with Jet A-1 or JP-8, and a few ground tests had to near $100 \%$ alternate fuels. Basically, alternate aviation fuels are termed "drop in" fuels because they pretty much "walk, talk, act, smell, and perform" like Jet A-1 or JP-8. Alternate fuels, based on diverse but approved feedstocks, conform to MIL-DTL83133F (2008) or ASTM D7566 (2010) standards and along with life cycle greenhouse gas emissions analyses provide the basis for a unified aviation industry position on alternative fuels [16]. 


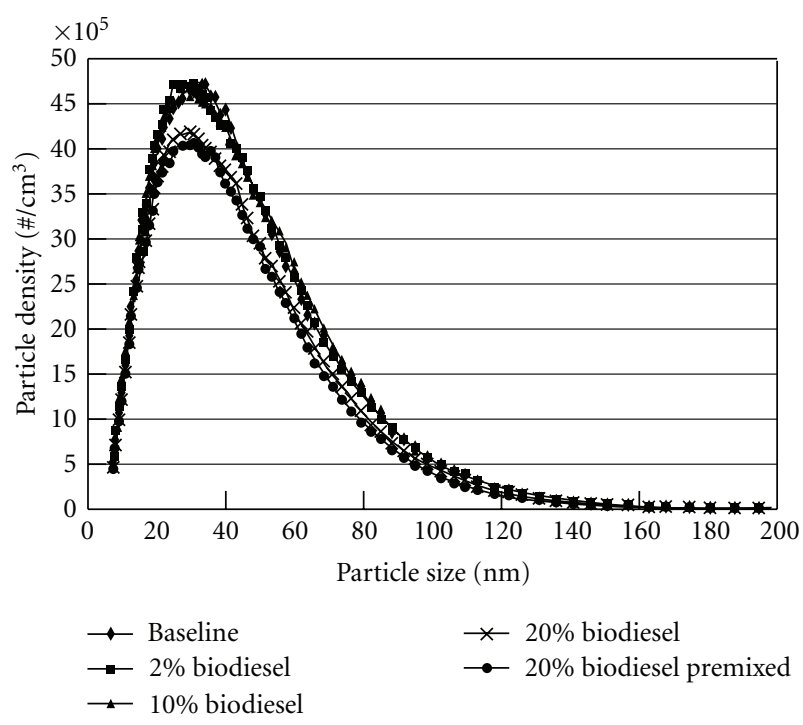

Figure 3: Particulate distribution from T63 gas turbine engine fueled with JP-8 and JP-8/biodiesel blends [8].

Edwards [17] cites a high-level USAF goal of purchasing 400 million gallons of alternative fuel by 2016 while working jointly with the CAAFI (Commercial Aviation Alternative Fuel Initiative) group to harmonize specifications and create an alternate fuels market. Currently, the USAF buys about 2.5 billion (B) gallons of jet fuel per year with the U.S. aviation industry buying near 26B gallons per year $[16,17]$.

2.2. General Aviation. Dr. Brien A. Seeley's goal for the Comparative Aircraft Flight Efficiency (CAFÉ) Foundation [18] is performance and biofuel blends with 100LL AvGas (general aviation piston engine fuel) to reduce and eventually remove lead. Baylor University's renewable aviation fuels program (RAFDC) is testing ethanol-ethyl tert-butyl ether (ETBE) [19], an oxygenate gas additive, in a Cessna 152 (recall ethanol to $10 \%$ is good gasoline additive). The Embraer EMB-202A aircraft consumes ethanol [20-22] and the Antonov 2 N244MJ should be capable of blended biofuels [23], and the first biofueled jet flight, an L-29, was fueled with a blend of vegetable oils [24].

\section{Why and How Are Hydrocarbon Heat Engines Hazardous?}

3.1. Emissions Hazards. The EPA classifies emissions as health hazards. Greenhouse gases contribute to air pollution and "...threaten the public health and welfare" $[25,26]$. All of the primary greenhouse gases qualify as air pollutants and can be regulated by the EPA under CAA-Massachusetts Supreme Court ruling, 2 April 2007 [27, 28].

Greenhouse gases (GHGs) include $\mathrm{CO}_{2}, \mathrm{CH}_{4}(25 \times$ worse than $\left.\mathrm{CO}_{2}\right)$, and $\mathrm{NOx}\left(\mathrm{N}_{2} \mathrm{O}, 300 \times\right.$ worse than $\left.\mathrm{CO}_{2}\right)$. The Environmental Protection Agency (EPA) has declared these hazardous to climate and health (e.g., excess $\mathrm{CO}_{2}$ in body lowers $\mathrm{pH}$ (acidosis)).
Particulates affect the climate and major undeclared health hazards (e.g., cardiovascular and lung diseases). Emphysema in coal miners may be related to hypersecretion of reactive forms of oxygen and may act to destroy pulmonary tissue. The Centers for Disease Control (CDC) notes that direct exposure to diesel-engine exhaust may decrease phagocytic capacity of alveolar macrophages [29] and points out the complexity of predicting affects of exposure. Others have disagreed with carcinogenic assessments; citing diesel soot inhalation had been improperly related to cancer risk and not high risk as other publications implied [30]. Hesterberg and Bunn [31] claim that high levels of particulate matter from new diesel engines only inflict mild transitory inflammation response. They do acknowledge possible thrombogenic and ischemic effects. Chronic inhalation at 10-30 times ambient diesel exhaust animal test exposures gave no adverse effects. However, clean room and spacecraft particulate concerns engendered new instrumentation to sample and monitor particles in the Space Shuttle Cabin during orbit. Samples collected were divided into four categories of particulates: 0-2.5, 2.5-10, $10-100$, and $>100 \mathrm{~nm}$. Postflight data provides particle mass, concentration and distribution, elemental composition, and morphology [32]. Particulates in the nanometer range are potential severe pulmonary toxicants. Toxic gases such as $\mathrm{HCl}$ and $\mathrm{HF}$ affect the upper respiratory tract, whereas surrogate $\mathrm{TiO}_{2}$ (12 and $\left.20 \mathrm{~nm}\right)$ and carbon black $(20 \mathrm{~nm})$ particulates penetrate deeper into the lungs. Combined effects of particulate inhalation and thermal breakdown can engender high toxicity [33]. Subsequently, the Oberdorsters provided both a review and needed research of nanotechnology's impact on human health. They focused on nanoparticulate (natural and engineered) uptake via the lung, GI tract, or skin, seeking to determine if and to what degree translocation pathways exist and which physicochemical properties control entry into blood and lymph circulation with potential to distribute and lodge in body organs [34].

All hydrocarbon- (HC-) fueled heat engine exhaust emissions contribute as health hazards where exhaust (tailpipe) emissions $(<10-140 \mathrm{~nm})$ include aircraft and mobility/stationary systems. In the case of particulate pollution (Table 1), Simkhovich et al. [35] have shown that ultrafine particulates directly translocate to promote vascular system diseases, and Schwartz [36] among others linked chronic respiratory diseases to particulates that are better known in terms of diagnosis and treatment.

ALL HC-fueled heat engines are major sources of these hazardous emissions.

With particulate inhalation of size similar to $5 \mu \mathrm{m}$, you cough it out. With nanoparticulates $(<100 \mathrm{~nm})$, quantum mechanical forces come into play and particulates can lodge in tissue. With distribution peaks ranging from 20 to $60 \mathrm{~nm}$, the residence time and toxicology of particulates become similar to the classic grain of sand in the oyster. Does such a lodged nanoseed form a resident benign nodule, eventually released by the lymphatic system, or does it serve as a tumor initiator and subsequent source of demise? 


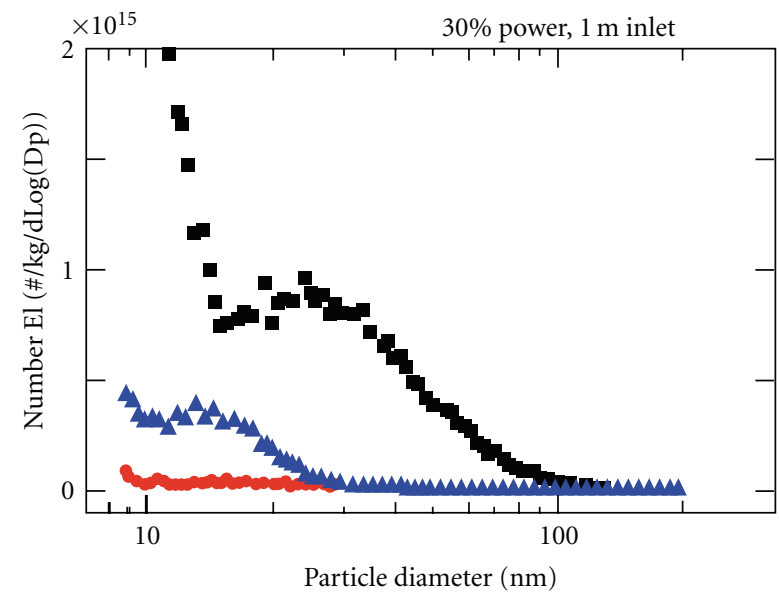

(a)

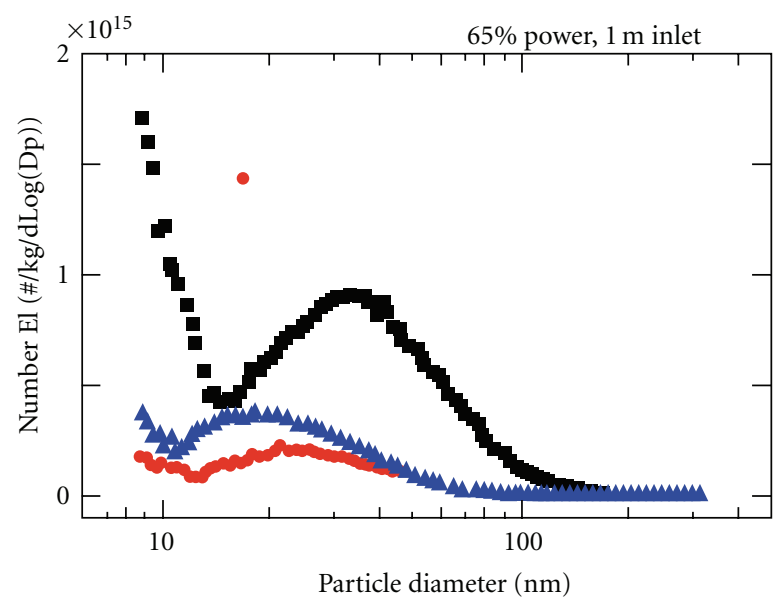

- JP-8

- FT2

4 Bld2

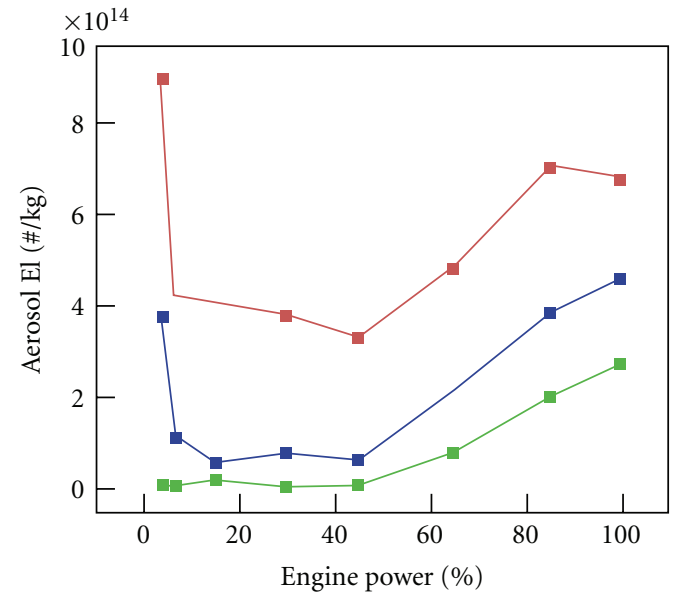

(b)

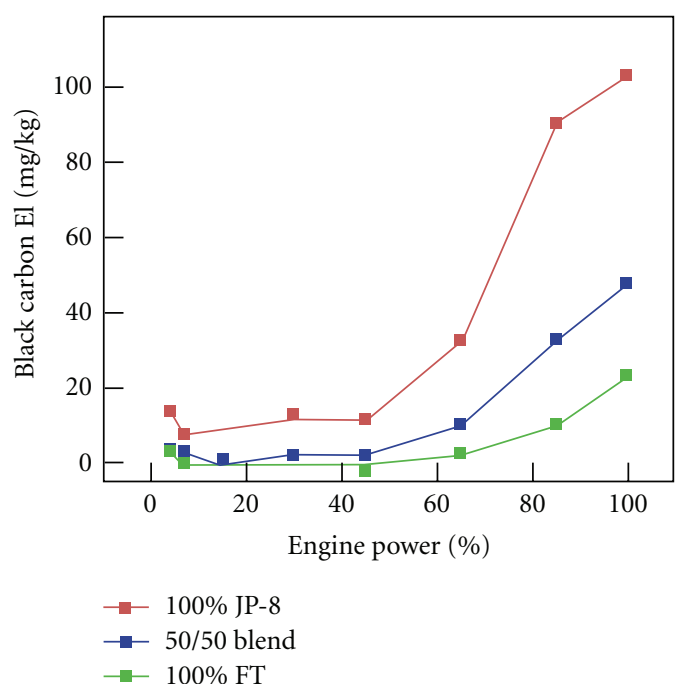

(d)

Figure 4: On-wing engine emissions testing measurements for particulates with JP-8, 50:50 blend JP-8 and S8, and 100\% S8, where S8 represents a Fischer-Tropsch fueling with either CTL or GTL jet fuel [9].

TABle 1: Particulate sizes classified by aerodynamic diameter.

\begin{tabular}{ll}
\hline Classification & Examples \\
\hline Coarse: $2.5-10 \mu \mathrm{m}(\mathrm{PM} 10)$ & Road and agricultural dust, tire wear \\
Fine: $<2.5 \mu \mathrm{m}(\mathrm{PM} 2.5)$ & $\begin{array}{l}\text { Gas to particulate conversion in combustion and industrial } \\
\text { processing }\end{array}$ \\
Ultrafine: $<0.1 \mu \mathrm{m}(<100 \mathrm{~nm})$-nanomaterial particulates & $\begin{array}{l}\text { Exhaust emissions (tailpipe), such as aircraft HCfueled } \\
\text { mobility/stationary systems }\end{array}$ \\
\hline
\end{tabular}

3.2. Hydrocarbon-Fueled Engine Emissions. Gas turbine, diesel, and gasoline engines are well-known HC-fueled engines.

Diesel engine emissions operating on petroleum-based fuels are well established [7], and many have been run on bioderived fuels with and without processing. In an
EPA engine test-fueled with 20\% soy-biodiesel and $80 \%$ petroleum diesel, NOx increased 2\% and PM, HC, and CO decreased $10.1 \%, 21.1 \%$, and $11.0 \%$, respectively [7].

Biodiesel emissions are dependent on feedstock (soybean, rapeseed, or animal fats) and engine type but not model year, implying combustor type and injection system 


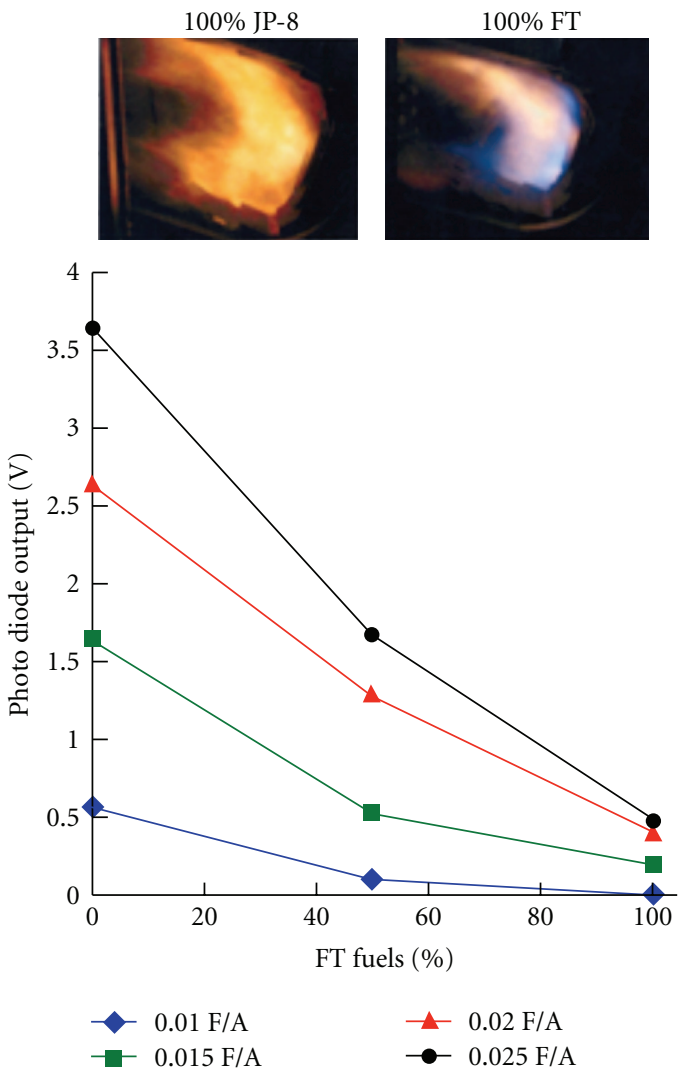

(a)

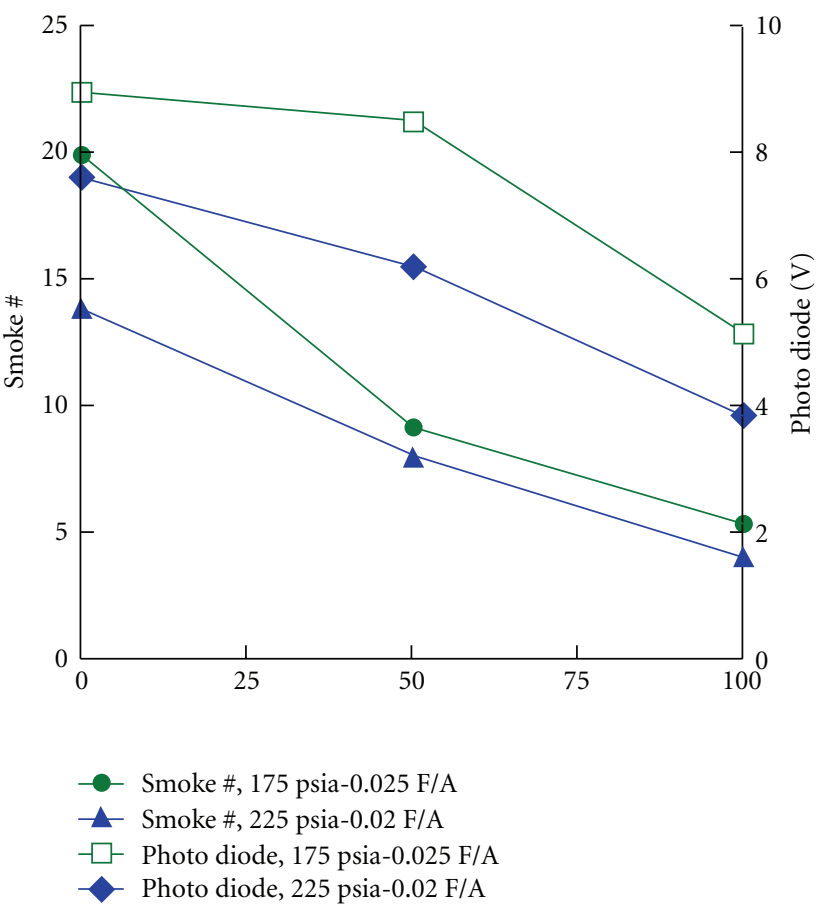

(b)

Figure 5: Combustor sector smoke number and luminosity test results for JP-8+100 fueling and blends with S8 varying from $0 \%$ to $100 \%$. Photo inset $(\mathrm{P}, \mathrm{T})$ inlet $=\left[75 \mathrm{psia},(0.517 \mathrm{MPa}), 500^{\circ} \mathrm{F}(533 \mathrm{~K})\right]$ at $3 \%$ combustor pressure drop. Smoke number is dimensionless; yet it is usually expressed as $\mathrm{mg}$ of soot $/ \mathrm{kg}$ of exhaust.

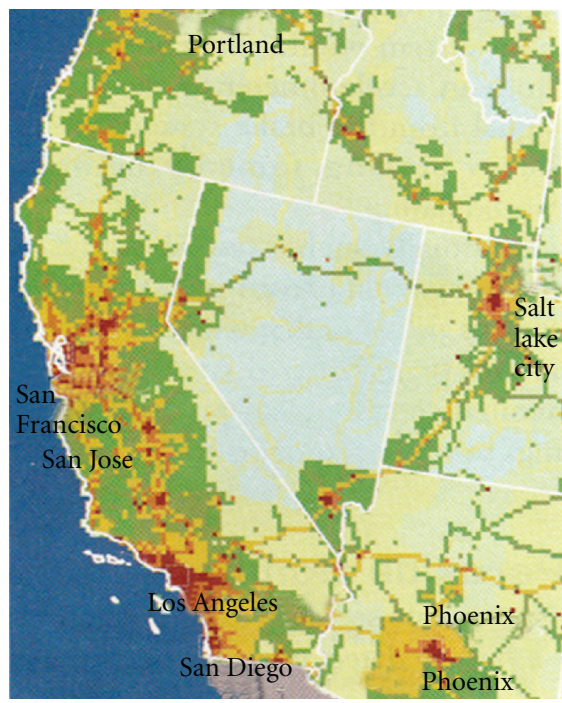

(a)

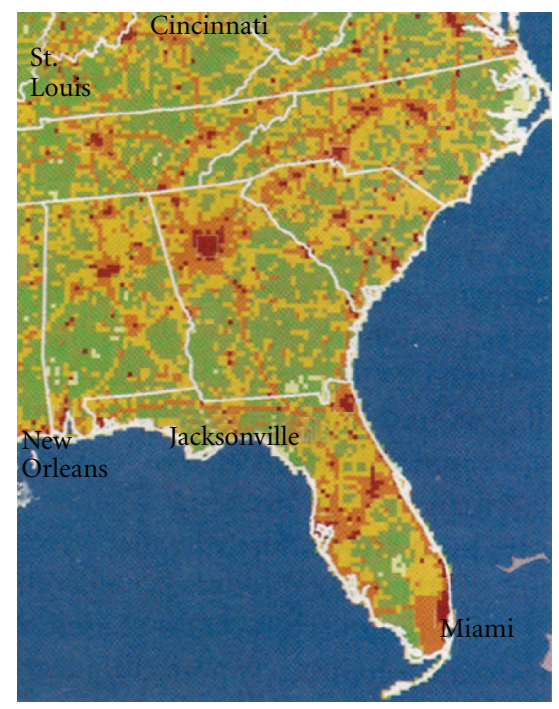

(b)

FIGURE 6: Tracking carbon emissions across the United States [10]. 


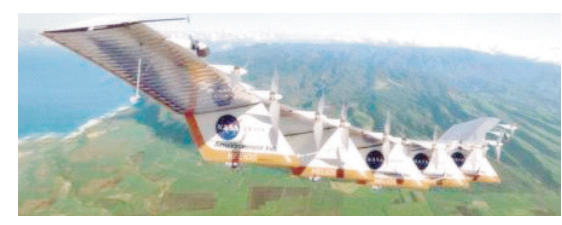

Solar-powered Helios and Zephyr

(a)

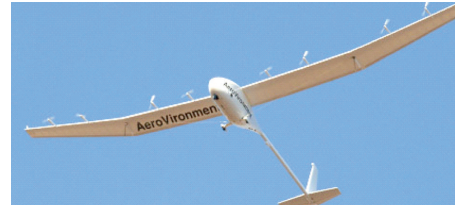

UAV-global observer LH2

(b)

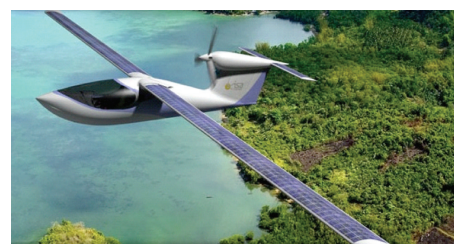

Lisa GH2

(c)

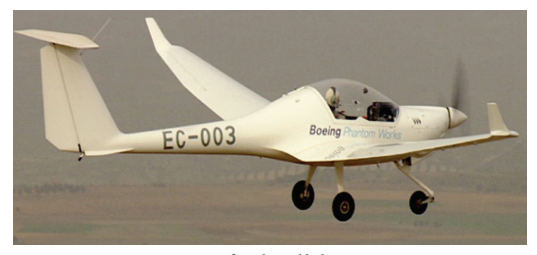

Boeing fuel cell/battery

(d)

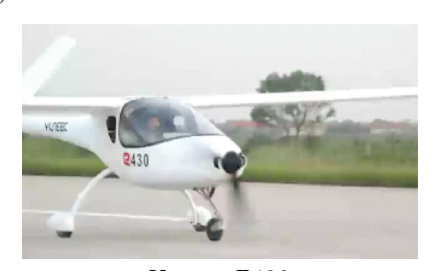

Yuneec E430

(e)

FIGURE 7: General aviation electric-powered aircraft [11].

TABLE 2: NASA subsonic transport system-level metrics (From http://www.aeronautics.nasa.gov/calendar/era_preconference_synopsis.htm).

\begin{tabular}{lccc}
\hline Corners of the trade space & $\begin{array}{c}N+1=2015^{*} \text { Technology } \\
\text { benefits relative to a single aisle } \\
\text { reference configuration }\end{array}$ & $\begin{array}{c}N+2=2020^{*} \text { Technology } \\
\text { benefits relative to a large twin } \\
\text { aisle reference configuration }\end{array}$ & $\begin{array}{c}N+3=2025^{*} \text { Technology } \\
\text { benefits }\end{array}$ \\
\hline $\begin{array}{l}\text { Noise, dB(cum. below Stage 4) } \\
\text { LTO NOx emissions, \%(below }\end{array}$ & -32 & -42 & -71 \\
CAEP 6)* & -60 & -75 & Better than -75 \\
$\begin{array}{l}\text { Performance:aircraft fuel burn, } \\
\text { Performance:field length, } \%\end{array}$ & $-33^{* * *}$ & $-50^{* * *}$ & Better than -70 \\
Pat & -33 & -50 & Exploit metro-plex concepts*** \\
\hline
\end{tabular}

${ }^{*}$ Technology Readiness Level for key technologies $=4-6$. N represents current aviation technology, For example, Boeing 787.

** LTO is landing-take-off cycle and CAEP is Committee on Aviation Environmental Protection.

*** Recently updated. Additional gains made are possible through operational improvements.

$* * * *$ Concepts that enable optimal use of runways at multiple airports within the metropolitan area.

similarities between the manufacturers. Figure 1 represents average emissions with \% biodiesel for heavy-duty highway engines.

With variations in fueling properties, heat engines produce emissions that need to be corrected for fuel heating value. Actually, for turbomachines such as aircraft gas turbines, the most common Fisher-Tropsch (FT) fuels and biofuels processed to meet JP8/JetA1 specifications (e.g., HRJ) all have about the same heat of combustion value in terms of mass $(-\mathrm{kJ} / \mathrm{g})$ - about 44 -with some variability in terms of decreased energy per unit volume $(-\mathrm{kJ} / \mathrm{liter})$ of fuel- $0 \%$ to $9 \%$ - depending on fuel blend, feedstock, and processing). The impact on $\mathrm{CO}_{2}$ aircraft gas turbine emissions release is essentially that of JP8/JetA1 except for particulates. Yet in terms of life cycle analysis, the biofuels are less than half that of JP8/Jet A1, or FT fueling and under properly managed conditions, future biomass-blended aviation fueling could become carbon negative, sequestering more carbon than released [37].

3.2.1. Aircraft Gas Turbine Engines Emissions Goals. While the aviation industry has no legislated standards, both military and commercial aviation are acutely aware of the impact of emissions, and more recently NASA has established intended emissions reductions goals (Table 2) along with complementary programs shown in Table 3.

3.2.2. Aircraft Gas Turbine Engines. In general for every $1 \mathrm{~kg}$ of fuel burned, an aircraft will produce $3 \mathrm{~kg} \mathrm{CO}$. Aviation emissions are highly dependent on aircraft and its operations cycle with more emissions generated at take-off (TO) and less at cruise. Some in-flight measurements have been made; yet reliable, on-ground, on-wing testing has been carried out by a consortium under Government contract with right in-board engine (\#3) running on various fuel blends. The calibrated probe rakes are established at various distances from the engine exhaust plain [38].

These specialized rakes, probes, aspiration lines, coupling characteristics, and recording methodologies, all of which impact both the measurement and accuracy, are beyond the scope of this paper. For further details see $[8,13,38]$, and for noncombustion applications, see [32].

On the ground, engine-on-wing emissions test data differ from altitude tunnel engine test data but are considered more representative of actual flight conditions. Both show particulate size and mass changes with engine power and 
TABle 3: Complementary Government research programs (From http://www.aeronautics.nasa.gov/calendar/era_preconference_synopsis .htm).

\begin{tabular}{|c|c|c|c|c|c|}
\hline Agency* & Project or activity** & Funded years*** & Vehicle focus $* * * *$ & $\begin{array}{l}\text { Proposed } \\
\text { TRL }{ }^{* * * * *}\end{array}$ & $\begin{array}{c}\text { Goal: Major } \\
\text { reduction/Minor } \\
\text { reduction }\end{array}$ \\
\hline FAA & CLEEN & FY10-FY14 & $N+1$ & $6-7$ & $\begin{array}{c}\text { Noise } \\
\text { Emissions } \\
\text { Fuel burn }\end{array}$ \\
\hline DoD & $\begin{array}{c}\text { ADVENT/HEETE/AD- } \\
\text { HEETE }\end{array}$ & FY10-FY14 & $N+2$ & $>6$ & Fuel burn Noise Emissions \\
\hline NASA & ERA & FY10-FY14 & $N+2$ & $4-6$ & $\begin{array}{l}\text { Simultaneous } \\
\text { Noise Emissions } \\
\text { Fuel burn }\end{array}$ \\
\hline NASA & SFW \& SUP & FY10-FY14 & $N+3$ & $2-4$ & $\begin{array}{l}\text { Noise } \\
\text { Emissions } \\
\text { Fuel burn }\end{array}$ \\
\hline DoD & RCEE & FY10-FY14 & Beyond $N+3$ & $2-6$ & $\begin{array}{l}\text { Fuel burn } \\
\text { Emissions } \\
\text { Fuel burn }\end{array}$ \\
\hline
\end{tabular}

\footnotetext{
** CLEEN is the Continuous Lower Energy, Emissions, and Noise program. ADVENT is the Adaptive Versatile Engine Technology program.

HEETE is the Highly Efficient Embedded Turbine Engine program.

AD-HEETE is a follow-on to ADVENT and HEETE programs.

ERA is the Environmentally Responsible Aviation program.

SFW is the Subsonic Fixed Wing project.

SUP is the Supersonics project.

RCEE is the Revolutionary Configurations for Energy Efficiency program.

VAATE is Versatile Affordable Advanced Turbine Engines program.

$* * * \mathrm{FY}$ is fiscal year.

$* * * * \mathrm{~N}$ represents current aviation technology for example, Boeing 787.

$* * * * *$ TRL is Technology Readiness Level.
}

*FAA is the Federal Aviation Agency; DoD: Department of Defense; NASA: National Aeronautics and Space Administration.

fueling; yet tunnel test results are lower than flight-test ground emissions test data [9].

Aircraft engines fueled with blends of FT-derived fuels (CTL and GTL), classified as SPK-Jet A-1 50:50 blend, show reductions in particulate emissions to $40 \%$ at ground idle engine speed but see that margin steadily decreases with increased engine power setting (Figure 2). Particulate emission reductions to $80 \%$ at ground idle are demonstrated at $100 \%$ SPK, but again, these reductions diminish with power increases. Similar trends are anticipated for biojet (HRJ) fuels since the hydrocarbon profiles are similar [14].

Whereas the static ground aircraft engine test results for the CTL- and GTL-processed fuels do indicate a reduction in particulate levels when compared with Jet A-1, the distributions for these tests (in terms of number and size) are close to being similar with a peak in the $25 \mathrm{~nm}$ range, rather independent of biodiesel blend of $0 \%, 2 \%, 10 \%, 20 \%$, and $20 \%$ premixed (Figure 3 ). Other tests show peaks from 20 to $60 \mathrm{~nm}$. Also to be noted are the unregulated auxiliary power unit (APU) gas turbine exhaust emissions, which are significantly higher than propulsion gas turbines (an issue in need of resolution).

On-wing gas turbine engine ground tests with petroleum-based JP-8 show similar trends (Figure 4). Petroleum-based JP-8 particulates as well as blends of JP-8 and FT fuels (CTL Sasol and GTL Shell) show significant increases in particulate emissions below $10 \mathrm{~nm}$ depending on engine power setting. With increases in engine power from $30 \%$ to $65 \%$, JP-8 particulate peaks shift from 18 to 35 $\mathrm{nm}$ with an increasing peak with FT fueling. The reduction in particulate emissions and black carbon number are most pronounced at idle but as shown in Figure 2 diminish considerably near $100 \%$ or the take-off power setting.

The black carbon and smoke number variations are also reflected in combustor testing, as the luminosity decreases with increasing percentage of FT fueling, and pressure (equivalent to increases in engine power) as shown in Figure 5.

We know from published data and prior discussion that particulates of these sizes (less than $100 \mathrm{~nm}$ ) lodge in the lung capillaries, and the smaller ones are able to penetrate into the venous system, returning to the heart with some lodging within the tissue and others in the arterial walls promoting cardiovascular disease.

There are several issues here.

(1) These particulates and distributions are common to all HC-burning heat engines including the gas turbine engines for aviation and engines for automobiles and power plants.

(2) We need to become more proactive to caution the energy community of the health hazards of HCfueled heat engine particulate emissions. 
(3) Carbon dioxide emissions are tracked at ground stations throughout the United States, and one can spot the major cities and interstates by mapping the $\mathrm{CO}_{2}$ emissions. Similar efforts could be employed for other emissions as $\mathrm{NOx}, \mathrm{CH}_{4}$, and VOCs, most of which are toxic and implicated in diseases. However, the distribution of particulates, to our knowledge, has not been tracked, nor has the effect of particulate release at altitude been tracked; more importantly the toxicology of those engine exhaust particulates under various climatic conditions has received little attention.

(4) While the $\mathrm{CO}_{2}$ emissions, and so forth, are currently classed as health hazards [25], the associated deadly issues of lung cancer and cardiovascular disease are overshadowed if not hidden and glossed over by the dynamics and politics of climatic-GHG affects.

(5) Also to the authors' knowledge, the U.S. disease center has not studied correlations between particulate distributions and disease distributions.

We are interested in the particulate size, distribution, and toxicology of those particulates, VOCs, and other gases and how body systems are affected by these elements, including their toxicology.

\section{Can We Detect Low-Level Hazardous Emissions and Particulates?}

4.1. A Basis for Detection. We want to detect the bad stuff before it happens. Emissions probes for aircraft exhausts are intrusive and difficult to design and implement, yet to a limited extent have been accomplished. Other exhaust sensors are less intrusive. For example, at NASA Glenn Research Center, Dr. Hunter [39] has developed exhaust gas radiation sensors for detection of specific elements primarily related to integrated health monitoring systems. He has also developed cargo bay gas-sniffers for detection of combustibles, which closely relates to needed emissions sensory work for humans and animals.

In the pioneering work of Lovgren [40] and Leung [41], dogs, which have a very distinctive and highly developed sense of smell, have been trained to sniff out "foreign elements" such as disease-specific odors (organic compounds). Diseased cells emit waste products different from those of normal cells that are excreted from the body and in particular exchanged in the lungs where emissions also play a major role, as also the case in the work of [42].

Nitric oxide (NO) is a hazardous emission. A problem is that NO is necessary for life, but too much of a good thing is usually toxic, and for air-oxidized combustion systems (heat engines, cigarettes, flue gas, etc.), such is the case. In asthmatics, where exhaled NO levels are higher than with nonasthmatics (still in ppb), NO enhances inflammation; detectable by chemiluminescence or laser diagnostics, the methods are both cumbersome and expensive. Hunter and Dweik are presently developing a system to detect and extract information from an asthmatic patient's breath using a portable low-cost solid-state sensor system. (Note that an EPA average air quality goal is $0.16 \mathrm{ppm}$ NO.)

The sensors of Hiack (9-element) and Hunter and Dweik along with associated electronics and transmitters could be "chipped" and made a mandatory part of every "closed atmosphere" transport vehicle (spacecraft, aircraft, automobile, even high-rise office space and homes) to detect emissions that are health hazards to the human anatomy and physiology. Coupled with telemedicine, such detection systems would provide early warning of disease and perhaps even their pathology [10]. Preventive in-flight cabin and spacecraft emissions sensing significantly reduces overall costs of medical care, drugs, and hospitalization (where applicable) and ensures greater safety of the traveling public or space explorer. Further, feedback loops could sharpen the sensitivity and selectivity of these electromechanical/chemical devices.

Herein, we are basically interested in emissions and data related to the particulates, VOCs, and their distribution and toxicology as they affect the body and organs because the cabin in aviation and space craft is one's survival membrane.

The hidden dangers of hydrocarbon-burning combustor emissions need our immediate attention.

\section{Can We Track These Emissions?}

5.1. Tracking Carbon and Ultrafine Emissions. Since the 1950 s global emissions have increased with $\mathrm{CO}_{2}$ levels rising from 300 to near $400 \mathrm{ppm}$. Increased $\mathrm{CO}_{2}$ levels affect both plant biomass and human respiration in terms of expulsion of $\mathrm{CO}_{2}$ (a toxicity issue). In fact pictorial images of $\mathrm{HC}$-fueled heat engine mobility corridors and population centers are readily outlined throughout the United States [10] (Figure 6). With heat engines there is an implied direct link between Cemissions measurements and ultrafine (nano)particulate emissions, as shown in Figure 1.

Some systems are more visibly tracked, such as anthropogenic particulate formations and volcanic eruptions where pyroclastic debris is deadly. Still interesting materials can evolve from such extreme events. Pozzolana, the basis for pozzolantic materials, is reported to form from the longterm exposure of erupted ash to atmospheric $\mathrm{H}_{2} \mathrm{O}$ and $\mathrm{CO}_{2}$, transforming the original complex silicates into a fine dust of simple silicates and oxides $\left(\mathrm{SiO}_{2}, \mathrm{Al}_{2} \mathrm{O}_{3}, \mathrm{Fe}_{2} \mathrm{O}_{3}\right)$. When reacted with lime, $\mathrm{Ca}(\mathrm{OH})_{2}$, they harden into insoluble calcium silicates and aluminates more resistant to aging $[43,44]$. While indirectly related to turbine engine emissions, sand, ash, earth soils, and debris ingestion into gas turbines becomes heat engine-transformed exhaust products. (Large amounts produce flameout-highly undesirable). Examples such as sand, soil, and aerosol particulates to $20 \mathrm{kft}$ altitude, ingested into and transformed by heat engines, may produce products that contribute to health hazards even when aircraft ventilation systems are HEPA filtered. Such studies need to be added to the Oberdosters' list of research data [34] to determine impact of such particulates on living tissue. 
5.2. General Aviation Emissions Response. Although in its infancy, electric-powered light aircraft sustained by combinations of solar, hydrogen-fuel cell, and battery is poised as general aviation's solution to aircraft emissions pollution. Examples vary from military unmanned aerial vehicles (UAVs) to the Chinese Yuneec E430 54-hp two-seat batterypowered electric airplane (Figure 7) [45].

Electric motors are challenged by water but work well at altitude where the aircraft is more efficient. While low- to no$\mathrm{CO}_{2}$ emissions hydrogen fueling is an attractive alternative and novel to general aviation, we need also to remember that commercial aviation was built upon general aviation. We also need to assess the impact of such an all-electric-power conversion system impact on living tissue.

\section{Conclusions}

(1) Alternate-fueled diesel and gas turbine engines whether sourced from CTL, GTL, or biomass feedstocks represent near-paraffinic hydrocarbon blends with Jet A-1 or JP-8 that perform as well as or better than petroleum-based fuels, yet produce less aviation emissions. Life cycle attributes are not addressed herein but tend to favor biomass feedstock fueling.

(2) EPA classifies emissions as health hazards that threaten the public health and welfare.

(3) Emissions can be tracked and mapped, outlining major transportation routes and cities.

(4) All hydrocarbon- (HC-) fueled heat engine exhaust emissions are health hazards; exhaust (tailpipe) emissions $(<10-140 \mathrm{~nm})$ include aircraft and mobility/stationary systems. Particulate pollution affects living tissue and is found to be detrimental to cardiovascular and respiratory systems where ultrafine particulates directly translocate to promote vascular system diseases.

(5) Diseased organic vapors are detectable and constitute an early warning system, which when combined with telemedicine could institute a major advance and cost reduction in medical care.

(6) ALL HC-fueled heat engines are major sources of these hazardous emissions. General aviation is developing electric and hydrogen-fueled propulsion systems, and unmanned aerial vehicles are already in use.

\section{References}

[1] Atlantic Greenfuels, "Sustainable Palm Oils, contact: J. R. Degenfelder," 2009, http://www.atlanticgreenfuels.com/.

[2] Atlantic Greenfuels, "Atlantic Greenfuels Workshop, contact: J. R. Degenfelder," 2009, http://atlanticgreenfuels.com/.

[3] Reuters, "Hanfeng Evergreen Completes Indonesia Joint Venture Agreement,"2009 http://www.reuters.com/article/2009/ 04/15/idUS112238+15-Apr-2009+MW2009.

[4] Evogene Ltd, "Evogene," 2009, http://www.evogene.com/.

[5] K. A. McVay and P. F. Lamb, "Camelina Production in Montana," Montguide, Montana State University,
Bozeman, MT, 2007, http://msuextension.org/publications/ AgandNaturalResources/MT200701AG.pdf.

[6] S. R. Schill, "Making Pennycress Pay Off," Biodiesel Magazine, Grand Forks, ND., 2008, http://www.biodieselmagazine.com/ articles/2047/making-pennycress-pay-off/.

[7] United States Environmental Protection Agency, "A Comprehensive Analysis of Biodiesel Impacts on Exhaust Emissions," EPA420-P-02-001, EPA, Washington, DC, USA, 2002, http://www.epa.gov/otaq/models/analysis/biodsl/p02001.pdf.

[8] E. Corporan, R. Reich, O. Monroig et al., "Impacts of biodiesel on pollutant emissions of a JP-8-fueled turbine engine," Journal of the Air and Waste Management Association, vol. 55, no. 7, pp. 940-949, 2005.

[9] B. Anderson, "Langley Aircraft Emission Research: Highlights and Overview of the Alternative Aviation Fuel Experiment," NASA Langley Research Center presentation, 2009.

[10] “"Making $\mathrm{CO}_{2}$ Visible," in Mechanical Engineering, J. Winters, Ed., ASME, New York, NY, USA, 2008.

[11] R. C. Hendricks, D. L. Daggett, and D. M. Bushnell, "Synthetic and Biomass Alternate Fueling in Aviation," in Workshop Report on Green Aviation, NASA Ames Research Center, S. Langhoff et al., Ed., Moffett Field, Calif, USA, 2009.

[12] Bureau of Transportation Statistics, "National Transportation Statistics, U.S. Department of Transportation Research and Innovative Technology Administration," Washington, DC, USA, 2007, http://www.bts.gov/publications/national_transportation_statistics/2007/pdf/entire.pdf.

[13] D. T. Shouse, C. Neuroth, R. C. Hendricks et al., "Alternate fueled combustor-sector performance," in Proceedings of the 13th International Symposium on Transport Phenomena of Rotating Machinery, Honolulu, Hawaii, USA, 2010.

[14] R. C. Hendricks, D. M. Bushnell, and D. T. Shouse, "Aviation fueling: a cleaner, greener approach," in Proceedings of the 13th International Symposium on Transport Phenomena of Rotating Machinery, Honolulu, Hawaii, USA, 2010.

[15] R. Ryder, R. C. Hendricks, M. L. Huber, and D. T. Shouse, "Computational analysis of dynamic SPK/HRJ-JP-8 (S8) fueled combustor-sector performance," in Proceedings of the 13th International Symposium on Transport Phenomena of Rotating Machinery, Honolulu, Hawaii, USA, 2010.

[16] Boeing, "Sustainable Aviation Fuel Users Group Our Commitment to Sustainable Options," Seattle, Wash, USA, 2009, http://www.boeing.com/commercial/environment/pdf/ sustainable_aviation_fuel_users_group.pdf.

[17] Atlantic Greenfuels, "Atlantic Greenfuels Workshop, T. Edwards presentation," contact: J. R. Degenfelder, 2009, http://www .atlanticgreenfuels.com/.

[18] CAFÉ Foundation, "CAFÉ News," Santa Rosa, Calif, USA, 2009, http://cafefoundation.org/v2/main_home.php.

[19] Wikipedia, “"Ethyl tert-butyl ether (ETBE)," 2009, http://en .wikipedia.org/wiki/ETBE.

[20] Baylor Institute for Air Science, “;Dr. Max Shauck Flying on Ethanol," Baylor Aviation, Waco, Tex, USA, 2006, http://www.youtube.com/watch?v=fR1kJ2z3zxM.

[21] J. Scott, "RARE in Waco," Rural Alliance for Renewable Energy, Austin, Tex, USA, 2005, http://www.infinitepower.org/ rare/events/Waco0505/waco0505.htm.

[22] Embraer, "Embraer EMB 202 Ipanema," Botucatu, Brazil, 2009, http://www.absoluteastronomy.com/topics/Embraer_ EMB_202_Ipanema.

[23] Wikipedia, ““Antonov An-2,” 2009, http://en.wikipedia.org/ wiki/Antonov_An-2.

[24] Green Flight International, "L-29 Rodante and Sugars," Apopka, Fla, USA, 2009, http://www.greenflightinternational .com/index.htm. 
[25] The Chicago Tribune, "EPA: Emissions Pose Health Risk," 2009, http://www.chicagotribune.com/features/green/chiobama-climate_dcapr18,0,6572389.story.

[26] Society of Environmental Toxicology and Chemistry, "SETAC", 2009, http://www.setac.org/.

[27] Massachusetts Supreme Court of United States, "Massachusetts et al. v. Environmental Protection Agency et al.," Syllabus No. 05-1120, 2006, http://www.supremecourtus .gov/opinions/06pdf/05-1120.pdf.

[28] United States Environmental Protection Agency, "Endangerment and Cause or Contribute Findings for Greenhouse Gases Under the Clean Air Act.," 2009, http:// epa.gov/climatechange/endangerment.html.

[29] Centers for Disease Control, "Chronic Inhalation Exposure to Coal Dust and /or Diesel Exhaust: Effects on the Alveolar Macrophages of Rats," Morbidity and Mortality Weekly Report, vol. 33, no. 7, pp. 101-102, 1984

[30] W. Stoeber, "On the health hazards of particulate diesel engine exhaust emissions," in Proceedings of the SAE Passenger Car Meeting and Exposition, 1987.

[31] T. W. Hesterberg and W. B. Bunn, "Critical Assessment of Health Studies on Diesel Exhaust," SAE Paper 2009-26-0012, 2009.

[32] B. Y. H. Liu, K. L. Rubow, P. H. McMurry, T. J. Kotz, and D. Russo, "Airborne Particulate Matter and Spacecraft Internal Environments," SAE Paper 911476, 1991.

[33] G. Oberdorster, J. Ferin, J. Finkelstein, R. Baggs, D. M. Stavert, and B. E. Lehnert, "Potential health hazards from thermal degradation events: particulate vs. gas phase effects," in Proceedings of the 22nd International Conference on Environmental Systems, pp. 1-15, July 1992.

[34] G. Oberdörster, E. Oberdörster, and J. Oberdörster, "Nanotoxicology: an emerging discipline evolving from studies of ultrafine particles," Environmental Health Perspectives, vol. 113, no. 7, pp. 823-839, 2005.

[35] B. Z. Simkhovich, M. T. Kleinman, and R. A. Kloner, "Air pollution and cardiovascular injury. Epidemiology, toxicology, and mechanisms," Journal of the American College of Cardiology, vol. 52, no. 9, pp. 719-726, 2008.

[36] J. Schwartz, "Particulate air pollution and chronic respiratory disease," Environmental Research, vol. 62, no. 1, pp. 7-13, 1993.

[37] R. C. Hendricks, "Potential carbon negative commercial aviation through land management," in Proceedings of the 12th International Symposium on Transport Phenomena and Dynamics of Rotating Machinery, Honolulu, Hawaii, USA, 2008.

[38] D. L. Bulzan et al., "Gaseous and Particulate Emissions Results of the NASA Alternative Aviation Fuel Experiment (AAFEX)," in Proceedings of the ASME Turbo Expo 2010: Power for Land, Sea and Air (GT '10), Glasgow, Scotland, 2010.

[39] G. Hunter, NASA Glenn Research Center, private communication, 2009.

[40] S. Lovgren, "Dogs Smell Cancer in Patients' Breath, Study Shows," National Geographic News, Washington, DC, USA, 2006, http://news.nationalgeographic.com/news/2006/ 01/0112_060112_dog_cancer.html.

[41] R. Leung, "Can Dogs Sniff Out Cancer?” CBS 60 Minutes, New York, NY, USA, 2005, http://www.cbsnews.com/stories/ 2005/01/06/60minutes/main665263.shtml.

[42] G. W. Hunter and R. D. Dweik, "Applied breath analysis: an overview of the challenges and opportunities in developing and testing sensor technology for human health monitoring in aerospace and clinical applications," Journal of Breath Research, vol. 2, p. 31, 2008.
[43] A. Bonincontro, "What Are Pozzolanic Materials and What Is Their Role?" Helium, Inc., Andover, Mass, USA, 2002-2010, http://www.helium.com/items/607752-what-arepozzolanic-materials-and-what-is-their-role.

[44] A. L. Velosa and M. R. Veiga, "Pozzolanic MaterialsEvolution of Mechanical Properties," in Proceedings of the International Building Lime Symposium, Orlando, Fla, USA, 2005.

[45] Yuneec International, “e430,” Herts, UK, 2008, http:// yuneeccouk.site.securepod.com/Aircraft.html. 

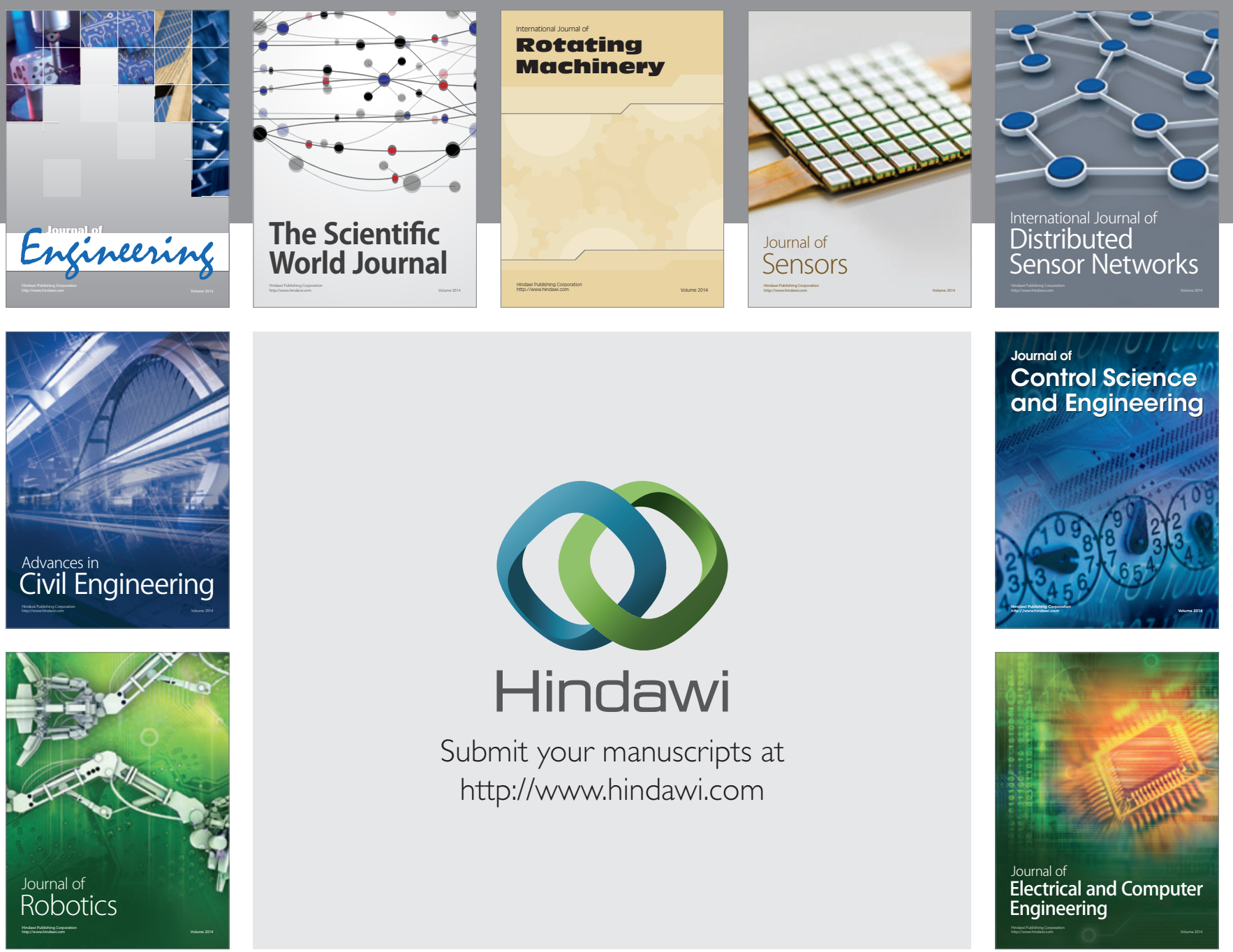

Submit your manuscripts at

http://www.hindawi.com
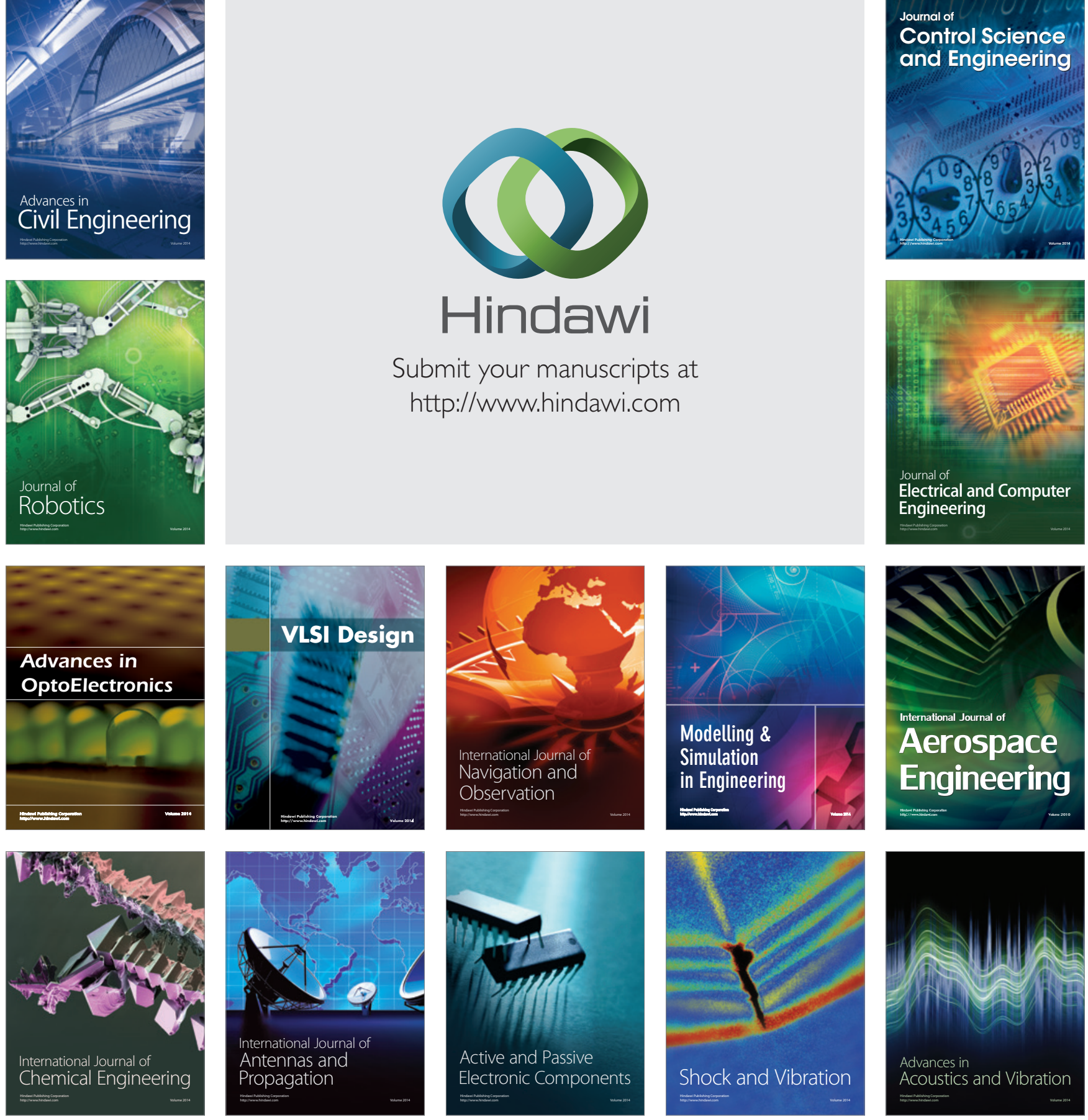